DOI 10.37882/2223-2982.2021.04.36

\title{
МЕТАФОРИЧНОСТЬ ПРОФЕССИОНАЛЬНОГО ДИСКУРСА ВОЕННОСЛУЖАЩИХ АРМИИ США (НА МАТЕРИАЛЕ СУБСТАНДАРТНОЙ ЛЕКСИКИ ВОЕННОГО ПОДЬЯЗЫКА)
}

\section{METAPHOR NATURE OF THE U.S. MILITARY PROFESSIONAL DISCOURSE (AS EXEMPLIFIED BY THE MILITARY LINGO SUBSTANDARD VOCABULARY) \\ K. Shnyakina}

Summary: The military sublanguage meets communicative needs of the military and has specific features. The military service lingo embraces normative and substandard lexical systems. The latter is expressive, codified, attitudinal, and imaginative. The subject area of the study is the phraseological layer of informal communication among U.S. military personnel. Based on linguistic evidence the author proves that metaphoricity of the military professional world image is fully reflected in unofficial routine discourse of the military.

Keywords: U.S. Armed Forces, service member, professional world image, military lingo, discourse, idiom, phraseological unit.

\author{
Шнякина Кира Вениаминовна \\ К.филол.н., доцент, Военный университет, Москва \\ 1881772@mail.ru
}

Аннотация: Военный подъязык обслуживает коммуникативные потребности армейского сегмента общества и характеризуется рядом особенностей. Подъязык военной службы образован нормированным и субстандартным лексическими пластами. Субстандартному варианту подъязыка военной службы присущи экспрессивность, оценочность, образность. Предметную область исследования составляет лексико-фразеологический пласт неформального разговорного общения военнослужащих армии США. Подкрепляется языковым материалом тезис о том, что метафоричность профессиональной картины мира военного человека находит свое воплощение в неофициальном дискурсе повседневного общения членов армейской среды.

Ключевые слова: вооруженные силы США, военнослужащий, профессиональная картина мира, военный подъязык, дискурс, идиома, фразеологическая единица.
B статье анализируется дискурс неформальной коммуникации американских военнослужащих. Объектом исследования избран подъязык военной службы США. Предмет исследования - профессионально отмеченные лексико-фразеологические единицы субстандартного пласта военного подъязыка. Целью работы ставится подкрепление тезиса о том, что профессиональная картина мира военнослужащего, отраженная в профессиональном подъязыке военной службы, в значительной степени метафорична.

Согласно традиционному подходу, под дискурсом понимается образ мышления, данный в системе понятий и выраженный в речи. Впервые понятие дискурса было детально проработано представителями французской школы дискурс-анализа, которая сформировалась к началу 70-х гг. XX века. Под дискурсом в широком смысле Э. Бенвенист понимал «всякое высказывание, предполагающее говорящего и слушающего и намерение первого определенным образом воздействовать на второго» [2, с. 279]. Дискурс интерпретируется как часть процесса коммуникации, однако при этом описываемый феномен выходит за рамки сугубо языковой системы.

Дискурс, согласно М. Фуко, представляет собой некоторое пространство, пронизанное общей идеей. Последняя объединяет различные тексты. Понимание конкретного дискурса невозможно без учета совокупности экстралингвистических факторов определенного хронотопа. Вместе с тем ученый подчеркивает вторичность личности пользователя языка по отношению к внешним факторам. Здесь важно отметить, что речь идет об идеологии, политической конъюнктуре, социальной иерархии конкретного общества в момент порождения речевого высказывания. Как социальный феномен, подчеркивает Фуко, дискурс реализуется в обществе через категории оценки, правил, запретов, предписаний [15, c. 33-35].

Положения французской школы получают широкое развитие в отечественной лингвистике. Дискурс, по мысли Н.Д. Арутюновой, есть сложный коммуникативный феномен. Кроме самого текста, дискурс отягощен совокупностью внеязыковых факторов. К числу последних отнесены знания о мире, мнения, установки, цели адресата, социальные практики [1, с. 136-137].

Под дискурсом В.Е. Чернявская понимает корпус тематически соотнесенных текстов, обслуживающих данную коммуникативную сферу. Содержание дискурса характеризуется интертекстуальностью. Дискурсивный анализ, по мысли Чернявской, «начинается с проецирования на элементы содержательно-смысловой и композиционно-речевой организации текста психо- 
логических, политических, национально-культурных, прагматических и других факторов» [11, с. 113]. Дискурс может быть интерпретирован как «коммуникативный и ментальный процесс, приводящий к образованию некой формальной конструкции - текста» [Там же, с. 115]. Дискурс аксиологичен, поскольку ценности выступают его необходимым компонентом. Ценности воплощены в аксиологических концептах, архетипах, стереотипах речевого и неречевого поведения, которые служат для передачи смыслов и интенций участников коммуникации.

Каждая профессионально отмеченная лексическая подсистема национального языка самобытна. Всякий подъязык раскрывает различные миры: политики, военного дела, религии, эстетики, медицины и т.д. Общенародный язык многогранен и соткан из множества подъязыков, детерминирующих наше существование. Ното Lingualis путешествует по дискурсам неустанно, попадая из одной сферы познания в другую. Любая дискурсивная формация, отмечает В.Н. Хаустов, очерчивает некое единое и неповторимое пространство. Сказанное позволяет заключить, что бытие и языковое сознание полидискурсивны. Общенародный язык или его вариант (диалект) распадается на множество лексических подсистем, каждая из которых, согласно теории языкового релятивизма Сепира-Уорфа, являет собой целый мир [10, с. 66-68].

Основу профессионального подъязыка (военнослужащих, врачей, экономистов, юристов, лингвистов) составляет национальный язык данного этноса, в то время как его специальная часть образована узко специализированными лексикой и терминологией [3, с. 68]. Тезаурус языковой подсистемы, обслуживающей определенный род профессиональной деятельности, стремится к понятийной строгости, ясности дефинирования, лаконичности. В профессиональной терминосистеме, отмечает Б.Л. Бойко, образное основание слова выхолащивается, стирается. Ср., например, тактические термины и устойчивые сочетания котел, клещи, охват, крыло / хвост самолета, оперенный снаряд, необитаемая башня танка, двунога / сошка и др.

Иная ситуация наблюдается сфере неформальной коммуникации. Для последней характерны живость речи, эмоциональность, образность. Военную субкультуру как часть культуры национальной (этнической) общности отличают особые «смыслы, эталоны вербального и невербального поведения, символы и стереотипы», служащие для номинации объектов предметной реальности в соответствии со спецификой армейской субкультуры [6, с. 35]. Наиболее ярко образность профессиональной картины мира прослеживается в жаргонной лексике. Ср., например, жаргонизмы hot officer - 'придирчивый офицер', hell's corner/live ammo / one-way ticket - 'опасный участок', liberty hound - 'любитель увольнений, отпусков', leaf / to earn one's leaf -'майор / получить воинское звание майора' (метонимический перенос связан со знаком различия на военной форме одежды армии США), man behind the man behind the gun - 'тыловик, служащий тыла', mother - 'авианосец', monkey flag - фам. пренебр. 'знамя части', monkey clothes - 'парадное обмундирование', hard and soft targets - 'укрепленные и легко уязвимые цели' и др. [8], [13].

В повседневном речевом общении фразеологическим единицам отведена особая ниша. Возникновение фразеологизмов в национальных языках, отмечает В.Н. Телия, происходит на основе образного отображения предметного мира [9]. Под внутренней формой фразеологической единицы, заключает Д.Б. Гудков, понимается то образное основание, которое служит для номинации предмета или явления окружающей действительности. Внутренняя форма ФЕ выступает в качестве носителя национально-культурной информации, закодированной в семантической структуре устойчивого словосочетания [4, с. 25-26]. ФЕ - особые сверхсловные наименования, наделенные культурно-исторической памятью.

Важным свойством фразеологизмов с исходной понятийной сферой «Война» выступает потенция к трансляции ценностных ориентиров, составляющих основу профессионального образа мира военного человека. Субкультурные константы, по А.С. Романову, представляют собой «аксиологически и функционально значимые паттерны мышления и поведения» представителей армейской части общества. Они имеют «официальную (декларативно-риторическую) и неофициальную (социолектную) вербализацию и детерминируют профессиональный образ мира социальной группы» [5, с. 96-97]. Военный подъязык, отмечает Б.Л. Бойко, двуедин. С одной стороны, он представлен нормированным литературным языком, а с другой - лексикой и фразеологией «разговорной речи с вкраплениями профессионализмов и единиц военного жаргона» [3, с. 68]. Использование ненормативных, не отвечающих литературному стандарту лексических единиц «связано со снижением уровня социального контроля и одобренной практикой неформальных отношений в данной социальной среде» [Там же].

В военной идиоматике подчеркиваются императивы профессионализма, боеготовности, высоких моральноэтических качеств воина. Ср., например, такие устойчивые выражения, как fortune favours the brave - 'смелость города берет', stick to one's guns - 'оставаться верным своим убеждениям до конца', to bite the bullet - 'стойко переносить тяготы и лишения военной службы', an empty suit / hollow Bunny - 'некомпетентный военнослужащий мужчина / женщина', all to the last man - 'один за всех и все за одного', fling oneself into the breach - 'прийти на выручку', hold (keep) the field - 'не сдавать позиций, сохранять доминирующее положение' и др. [8], [12], [13]. 
На основе проведенного анализа ряда публикаций качественной_американской прессы за период с 2012 по 2018 гг. (Chicago Tribune, New York Post, The New York Times, The Wall Street Journal, The Washington Post) A.C. Романов и М.A. Ангалева выделяют артефактную метафорическую модель "MILITARY SERVICE is WAY / ROAD"«ВОИНСКАЯ СЛУЖБА - это ПУТЬ / ДОРОГА». В основе названной модели лежит идея самоотречения сынов отечества, посвятивших свои жизни военной службе. Сема жертвенности воинского служения находит выражение в идиомах to die with one's boots on - 'погибнуть при исполнении воинского долга', to catch a bullet with your name on it - 'схлопотать пулю', a widow maker 'опасный в обращении предмет матчасти', to become a gold star in mom's window - 'nогибнуть в бою' и др. [7, c. 150]. Украшение фасадов зданий звездами имеет глубокий символический смысл. «Синяя звезда свидетельствует об участии члена семьи в боевых действиях. Красная звезда говорит о полученном ранении, бронзовая - свидетельство кастовой принадлежности к семье кадрового военнослужащего или ветерана». И, наконец, золотая звезда - политкорректное напоминание о том, что сын отдал свою жизнь во имя высших интересов родины [Там же].
Лексико-фразеологические единицы неформального повседневного общения военнослужащих отражают особенности профессиональной картины мира. В лексике и идиоматике неофициальной коммуникации запечатлены славные и трагические страницы истории, императивы и реалии военной службы, система ценностей носителя воинской культуры. Профессиональная группа военнослужащих обнаруживает совокупность отличительных особенностей, связанных главным образом с уникальным социокультурным опытом и функциональным предназначением социального института вооруженных сил. Проведенное исследование подводит нас к заключению о существовании обратно пропорциональной зависимости между степенью социального контроля и метафоричностью слововыражения. Чем выше степень такого контроля, тем ниже образность лексикона и наоборот.

Изучение специфики речевого репертуара американских военнослужащих в полной мере отвечает интересам профессиональной подготовки военных переводчиков, способствует сближению контактирующих этносов посредством налаживания взаимопонимания на уровне субкультур.

\section{ЛИТЕРАТУРА}

1. Арутюнова Н.Д. Дискурс / Большой энциклопедический словарь: под ред. В. Н. Ярцевой / Н.Д. Арутюнова // Языкознание М.: Большая Российская энциклопедия, 1998.709 с.

2. Бенвенист Э. Общая лингвистика / С. Бенвенист. Под ред. Ю.С. Степанова. М.: Прогресс, 1974. 448 с.

3. Бойко Б.Л. К проблеме образа мира российских военнослужащих / Б.Л. Бойко // Профессиональная картина мира. Методология. Варианты. Практика. Коллективная монография / под общ. ред. С.В. Мыскина и Е.Ф. Тарасова. М.: 000 «Агентство социально-гуманитарных технологий», 2020. С. 65-78.

4. Гудков Д.Б. Коды русской культуры: проблемы описания / Д.Б. Гудков // Мир русского слова. М.: Наука, 2005. № 1-2. С. 25-31.

5. Романов А.С. Аксиологический каркас профессионального образа мира военнослужащих США (на материале прецедентных текстов армейского официоза) / А.С. Романов // Профессиональная картина мира. Методология. Варианты. Практика. Коллективная монография / под общ. ред. С.В. Мыскина и Е.Ф. Тарасова. М.: 000 «Агентство социально-гуманитарных технологий», 2020. С. 95-109.

6. Романов А.С., Лупанова, Е.В. Дихотомические диады фразеологических единиц как средство выражения ключевых ценностей армейской субкультуры / А.С. Романов, Е.В. Лупанова // Филологические науки в МГИМО: Журнал. № 1 (21) 2020 / Гл. ред. В.А. Иовенко. М.: МГИМ0-Университет, 2020. С. $34-30$.

7. Романов А.С., Ангалева М.А. Вооруженные силы США в стереотипах американской периодики на примере метафорической модели “Military Service is Way / Road" / А.С. Романов, М.А. Ангалева // Современная наука: актуальные проблемы теории и практики. Серия: «Гуманитарные науки». 2019. № 4. С. 149-154.

8. Судзиловский Г.А. Сленг - что это такое? Английская просторечная военная лексика / Г.А. Судзиловский. М.: Воениздат, 1973. 182 с.

9. Телия В.Н. Фразеологизм // Русский язык: Энциклопедия. М.: Большая Российская энциклопедия; Дроф, 1997. С. 605-607.

10. Хаустов Д.С. Лекции по философии постмодерна / Д.С. Хаустов. М.: РИПОЛ классик, 2018. 288 с. (ЛекцииРRO).

11. Чернявская В.Е. Лингвистика текста. Лингвистика дискурса: учеб. пособие / В.Е. Чернявская. М.: Издательство «Флинта»: «Наука», 2013.208 с.

12. Axelrod A. Whiskey tango foxtrot: the Real language of the modern American Military / A. Axelrod. N.Y. Skyhorse Publishing, 2013. 240 p.

13. Dickson P. War Slang: America fighting words and phrases since the Civil War / P. Dickson. 2nd ed. Dulles, Virginia: Brassey's Inc, 2003. 428 p.

14. Foucault M. The Archaeology of Knowledge / M. Foucault // Trans. A.M. Sheridan Smith. London and New York.: Routledge, 2002. 239 p.

(с) Шнякина Кира Вениаминовна (1881772@mail.ru).

Журнал «Современная наука: актуальные проблемы теории и практики» 